\title{
Effect of Transformational Leadership on Organizational Commitment and Labour Performance
}

\author{
Andi Nur Insan ${ }^{1}$, Ahmad Safarudin ${ }^{2}$ \\ ${ }^{1}$ Universitas Indonesia Timur, Makassar, Indonesia \\ ${ }^{2}$ Sekolah Tinggi Ilmu Ekonomi Tri Dharma Nusantara Makassar, Indonesia
}

\begin{abstract}
The aim of research is to investigate the effect of transformational leadership and Burnout on organizational commitment and employee performance. Methods are explanation research with survey meth-od. The location of this research conducted in Eastern Pearl Flour Mills Makassar company. Samples num-bered 78 people. The method of collecting data was stratified proportional random sampling consisting of managers, assistant managers, supervisors, and employees. The generalized structured component analysis (GSCA) is using to explore the relation of all variables. Results found that transformational leadership is not significant to the performance of employees. This result show is not suitable transformational leadership ap-plied in PT. Eastern Pearl Flour Mills.
\end{abstract}

Keywords: Transformational Leadership, Burnout, Organizational Commitment, and employee performance.

\section{Introduction}

Successful organization is the result of the behaviour of a leader who can motivates employees to achieve the vision and mission of the organization. At the same time, as the consequence of globalization era, the application of new technologies especially the information technology in dealing with an increasingly competitive environment of the company are needed to create more effective and efficient way to improve company performance. Therefore, the Transformational process can be seen through a number of leadership behaviours that: idealized influence, Inspirational motivational, Intellectual stimulation, Individualized consideration to improve the company performance. And at the same time can manage their company by using new information technology to improve the performance of the employee and improve the system of the company.

The leadership is a crucial factors in corporate system and in developing of employee productivity. A transformational leader is the leader of a reliable and delivery of organizational commitment and sense of common purpose for followers. [1]. Furthermore, the facts shows that there were positive effect of transformational leadership on organizational commitment and organizational change especially on employee performance. [2]. Another thing that can affect the performance of employees is burnout. The previous research revealed that there were significant effect of burnout on employee performance. Burnout is an exhaustion that integrates physical, mental and emotional because of the powerlessness of the situation facing workers. The cause is a lack of appreciation. Burnout can affect organizational commitment [3]

Organizational commitment is a psychological condition that characterizes the employee relationship with their organization and has implications on the decision to continue or stop employees from membership of the group. [4].
Performance variables of this research was measured by the indicators of quality of work, quantity of work, timeliness, cost efficiency, ability to carry out the work, and the ability of employees to build a working relationship, the adoption of [4]. Based on a review of theory and empirical research that has been described to be developed this research model to study the effect of transformational leadership and the burnout, organizational commitment and employee performance of PT. Eastern Pearl Flour Mills company in Makassar city. Customers PT. Eastern Pearl Flour Mills covers various regions across Indonesia, so that flour delivery system cannot be delayed. With the facts above, the purpose of this research is to investigate the effects of Burnout on transformational leadership and organizational commitment and employee performance.

\section{Research Methods}

The research method is surveyed quantitative with a critical approach. There are four variables of research are transformational leadership, burnout, organizational commitment and employee performance. The independent variables are transformational direction and burnout. The number of population of as many as 385 people and 78 people study sample consisted of managers, assistant managers, supervisors, and employees. The sampling technique of research is proportional stratified random sampling [5]. Data were analyzed using Generalized structured component analysis (GSCA) [6]. The GSCA model can analyze variables along with formative and reflexive indicators. Formative indicators form the variables studied. In this study, six formative indicators on employee performance variable and three indicators on burnout variables. The transformational leadership variable is reflected by 12 reflexive indicators, and six reflexive indicators are reflecting organizational commitment variables. 


\section{International Journal of Science and Research (IJSR) \\ ISSN (Online): 2319-7064}

Index Copernicus Value (2015): 78.96 | Impact Factor (2015): 6.391

\section{Result and Discussion}

\subsection{Organizational Condition}

The main products of PT. Eastern Pearl Flour Mills are four brands of wheat flour. All the flour kind produced with the main quality. The organization chart of the company is divided into 13 parts, namely:

1) Personnel in charge of planning and evaluating personnel administrative activities.

2) Production Development Quality Control Manager responsible for coordinating and ensuring all functions and responsibilities of quality control runs with effective. Quality control includes raw material and the quality of flour products.

3) Engineering and Utility Manager is assigned to the quality program and all operational activities.

4) Production Manager tasked with coordinating and directing and controlling all activities within Production Department, such as cleaning and milling process. Also, this unit must also ensure the smooth and efficient use of all types of work in the Production Department.

5) Shipping responsible for coordinating and controlling daily shipping, loading and unloading activities for incoming raw materials and filling in silos.

6) Quality Assurance is in charge of coordinating the developer of quality assurance activities at PT. Eastern Pearl Flour Mills.

7) Packing-Warehouse Manager is responsible for daily production planning, material retrieval and control of production and hygiene in the flour packing area while analyzing the production.

8) Logistic Assistant Manager duty to check and supervise all activities personnel logistic department which includes the process of distributing products from the factory to the customer warehouse.

\subsection{The relationship between independent variables and dependent variables}

The transformational leadership of PT.Eastern Pearl Flour Mills has significant positive effect on an organizational commitment to the critical value obtained significant at $95 \%$ confidence level and a 0,695 estimate value and the value of CR $28.35 *$. This result shows that transformational leadership can build organizational commitment. This research supports the Barling theory that revealed that the personal character of leaders affected on organizational commitment of employee. The leader ability to transform the command to an employee can increase the employee commitment. The result of research indicates that transformational leadership of corporate can engage the environmental and organizational change.

Furthermore, there is no significant transformational leadership on employee performance, the critical value obtained is not significant at the $95 \%$ confidence level. It can be interpreted that the Transformational leadership is not suitable to be applied in P.T. Eastern Pearl Flour Mills. The ideal is transactional leadership.
The other employee character that affected to their working performance is burnout. It indicates the psychological condition of human which unpleasant for a work situation. This research shows that burnout active and significant effect on organizational commitment as a critical value obtained significant at $95 \%$ confidence level. It indicates that although employees are experiencing burnout at work, they are still high organizational commitment because they get the reward according to the workload at the company. This research supports research which revealed that significant effect on the performance of burnout paramedics [7]. Furthermore, organizational commitment significantly influences employee performance due to a critical value at significant at $95 \%$ confidence level. It can be interpreted that the employees have a high organizational commitment so that the effect on employee performance. Limitations of this research, the lack of samples, because it does not involve employees working in the factory (the employees that can not be met).

The summary of the labor performance model is described in figure 1:

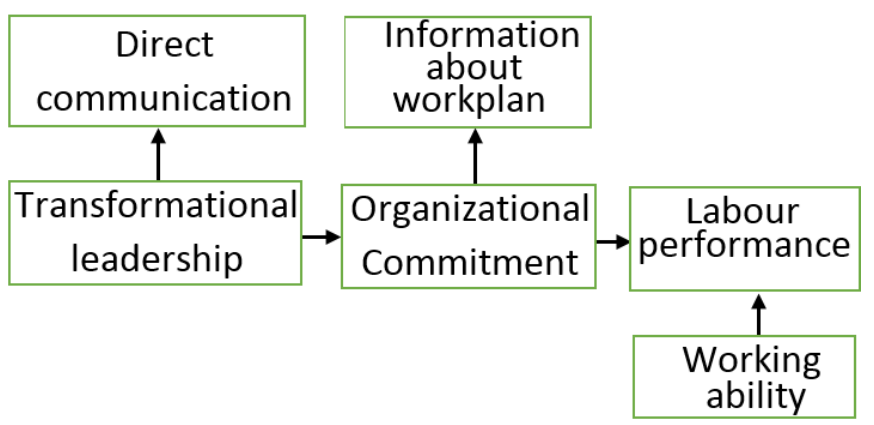

Figure 1: Labor performance model

\subsection{Discussion}

The best model should apply to PT Eastern Pearl Flour Mills is transformational leadership building organizational commitment. The commitment of employees together will give birth to optimal performance. As a basis for developing organizational commitment is clarity about work plan. Employees who work on the work plan will understand their roles and responsibilities in the completion of the work. Such clarity can facilitate the achievement of good performance.

Transformational leadership as a leader characteristic is crucial to building organizational commitment. The employee and leader commitment showed in their discipline, spirit, and working environment. The keyword of transformational leadership is Fostering the development of vision and goals, Developing a collaborative decisionmaking structure, Symbolising good professional practice, Providing individualized support, Providing intellectual stimulation and Holding high-performance expectations. [8] The model leadership of organizational is not significantly affected to the employee fulfillment. It can be interpreted that the direction was not suitable to apply in PT. Eastern Pearl Flour Mills.

The effect of burnout on organizational commitment showed the willingness and the satisfaction of employees to perform their real achievement. Although workers are experiencing burnout at work, they are still high organizational 
commitment because they get the reward according to the workload at the company. Organizational commitment significantly influences employee performance. It can be interpreted that the employees have a high organizational commitment so that the effect on employee performance.

\section{Conclusion}

Transformational leadership and significant positive impact on organizational commitment. It shows that transformational leadership can build organizational commitment. Transformational leadership is not necessary to the performance of the employee. Burnout active and meaningful effect on organizational commitment. Burnout powerful and significant influence on employee performance. Organizational commitment significantly influences employee performance.

\section{References}

[1] J. Barling, F. Slater, and E. Kevin Kelloway, "Transformational leadership and emotional intelligence: An exploratory study," Leadersh. Organ. Dev. J., vol. 21, no. 3, pp. 157-161, 2000.

[2] F. Bushra, U. Ahmad, and A. Naveed, "Effect of transformational leadership on employees' job satisfaction and organizational commitment in banking sector of Lahore (Pakistan)," Int. J. Bus. Soc. Sci., vol. 2, no. $18,2011$.

[3] D. U. Wahyuni, B. Christiananta, and A. Eliyana, "Influence of Organizational Commitment, Transactional Leadership, and Servant Leadership to the Work Motivation, Work Satisfaction and Work Performance of Teachers at Private Senior High Schools in Surabaya," Educ. Res. Int., vol. 3, no. 2, pp. 82-96, 2014.

[4] H. Bernardin, "John \& Russell, Joyce EA 1993," Hum. Resour. Manag., 1988.

[5] Y. Singh, Research Methodology. APH Publishing, 2010.

[6] H. Hwang and Y. Takane, "Generalized structured component analysis," Psychometrika, vol. 69, no. 1, pp. 81-99, 2004.

[7] D. W. Grigsby and M. A. Mc Knew, "Work-stress burnout among paramedics," Psychol. Rep., vol. 63, no. 1, pp. 55-64, 1988.

[8] D. Gurr, "Transformational leadership characteristics in primary and secondary school principals," Lead. Manag., vol. 8, no. 1, pp. 78-99, 2002. 